\title{
THE DEVELOPMENT OF NEUROINFLAMMATORY PROCESSES IN RATS IN EARLY POSTNATAL ONTOGENESIS AFTER PRENATAL HYPERHOMOCYSTEINEMIA
}

\author{
A.D. Shcherbitskaia ${ }^{1,2}$, D.S. Vasilev ${ }^{1}$, N.L. Tumanova ${ }^{1}$, Ju.P. Milyutina ${ }^{2}$, \\ I.V. Zalozniaia', A.V. Arutjunyan ${ }^{2}$ \\ ${ }^{1}$ I.M. Sechenov Institute of Evolutionary Physiology and Biochemistry Russian Academy of Sciences, \\ Saint Petersburg, Russia; \\ ${ }^{2}$ The Research Institute of Obstetrics, Gynecology and Reproductology named after D.O. Ott, \\ Saint Petersburg, Russia
}

\section{РАЗВИТИЕ НЕЙРОВОСПАЛИТЕЛЬНЫХ ПРОЦЕССОВ У КРЫС В РАННЕМ ПОСТНАТАЛЬНОМ ОНТОГЕНЕЗЕ ПОСЛЕ ПРЕНАТАЛЬНОЙ ГИПЕРГОМОЦИСТЕИНЕМИИ}

\author{
А.Д. Щербицкая ${ }^{1,2}$, Д.С. Васильев ${ }^{1}$, Н.Л. Туманова ${ }^{1}$, Ю.П. Милютина ${ }^{2}$, \\ И.В. Залозняя ${ }^{2}$, А.В. Арутюнян ${ }^{2}$ \\ ${ }^{1}$ ФГБУН «Институт эволюционной физиологии и биохимии им. И.М. Сеченова» РАН, \\ Санкт-Петербург; \\ ${ }^{2}$ ФГБНУ «Научно-исследовательский институт акушерства, гинекологии и репродуктологии \\ имени Д.О. Отта», Санкт-Петербург
}

nastusiq@gmail.com

Prenatal exposure to high levels of homocysteine has long-term impact on growth retardation of nervous system development and is related to central nervous system diseases in children. However, it is not well-characterized whether gestational exposure to hyperhomocysteinemia (HHC) affects the development of nervous system in offspring. It was observed disturbed neuroblast generation and migration, neuronal death in cortex, revealed as reduction of pyramidal neurons number, and activation of glia in the month after birth in offspring subjected to HHC. These disorders may be associated with changes in the content of proinflammatory cytokines in the cortex tissue of HHC pups.

Keywords: homocysteine; proinflammatory cytokines; cortex.

Повышение уровня гомоцистеина в крови матери во время беременности оказывает долгосрочное воздействие на развитие нервной системы и связано с заболеваниями ЦНС у детей. Тем не менее, механизмы, за счет которых гипергомоцистеинемия (ГГЦ) матери влияет на развитие нервной системы у потомства, охарактеризованы недостаточно. В нашем исследовании наблюдалось нарушение генерации и миграции нейробластов, гибель нейронов в коре, выраженная в уменьшении числа пирамидных нейронов и активации глии в течение месяца после рождения у крысят после пренатальной ГГЦ. Эти нарушения могут быть связаны с наблюдаемыми изменениями содержания провоспалительных цитокинов в ткани коры крысят, перенесших пренатальную ГГЦ.

Ключевые слова: гомоцистеин; провоспалительные цитокины; кора.

Introduction. Maternal hyperhomocysteinemia (HHC) is an independent and significant risk factor for pregnancy complications. In animal models, the maternal HHC induces persistent functional disabilities, learning deficits in offspring at early and late stages of postnatal development. Particularly little is known about the effects of increased maternal homocysteine on subsequent brain development of their offspring, especially at the structural level. In our study, we have used a set of tests in order to evaluate the consequences of prenatal $\mathrm{HHC}$ action on cell generation and migration into the developing cortical plate by evaluating the number and localization of cortical neurons in the postnatal ontogenesis of rats. We hypothesized that animals after prenatal HHC would present imbalanced levels of inflammatory cytokines in the brain.

Materials and methods. All animal experiments were performed in accordance with the Directive \#86/609 of the Council of European Communities. Pregnant female Wistar rats (total $n=21)$ were divided into two groups: control animals received drinking water per os daily throughout the pregnancy; HHC was induced in pregnant rats by administration of methionine $(0.6 \mathrm{mg} / \mathrm{kg})$ in drinking water.

Female rats on the 14th day of gestation were injected with a DNA-replication marker 5'ethynyl2 'deoxyuridine (EdU) to label cells generated in the proliferative zone destined to the cortical layers $\mathrm{V}$ and VI. To evaluate the position of neuronal cells 
generated on E14, the pups of female rats injected with EdU were decapitated on P5.

On P5 or P20 the structural abnormalities in pups cortical tissue were analyzed. Brain slices were Nissl stained and analyzed by light microscopy. We have also performed an analysis of the number of cells labeled by neuronal marker proteins in the same area of the parietal cortex as in the EdU visualization experiment. Visualization of the cell nuclei was performed using a blue-fluorescent dye DAPI. The number of neurons was analyzed using mouse monoclonal anti-Fox3 $(=\mathrm{NeuN})$ antibody. The comparison in the number of Fox3-positive (living neurons) and Fox3-negative (glial cells and degenerated neurons) was performed for cortical cells in control and prenatal HHC pups in parietal cortex.

Cytokine (TNF- $\alpha$, IL-1 $\beta$ and IL-6) measurement was performed in cortex of pups on P20 with a commercial ELISA kit (R\&D systems, USA).

Results and discussion. Analysis of the consequences of prenatal HHC action during embryogenesis on brain development in animals and humans is important for understanding the underlying mechanisms of neonatal pathologies and prognosis of their outcome in later life. Our previous studies have shown that maternal HHC led to cognitive dysfunction in rat offspring (Shcherbitskaya et al., 2017). To investigate the underlying mechanisms of the impairment caused by prenatal HHC we have performed detailed analysis of development of the parietal cortex of rats.

In rat pups exposed to various harmful stimuli during embryogenesis, migration of neuroblasts is compromised in different cortical areas because the mechanisms of radial migration of neuroblasts are rather common (Rakic, 1988). According to our data in the group of pups on P5 subjected to prenatal HHC the total amount of labeled cells in the parietal cortex was decreased while the number of labeled neurons scattered within the superficial cortical layers was increased. Our data suggest that maternal $\mathrm{HHC}$ results in a disruption in neuroblast generation and migration into their proper position in the layers V-VI of the parietal cortex of pups. Similar findings have been reported in offspring with different non-HHC models of prenatal pathology (Vasilev et al., 2016). We also observed such features of neuronal death as reduction in the total number of pyramidal cortical neurons, chromatolysis, increase in the number of glia cells, suggesting an activation of cortical neuroglial cells in rat offspring on P20 after gestational exposure to HHC.

In most cases, activated glia initiate neuroinflammation by producing cytotoxic and inflammatory factors such as the cytokines IL- $1 \beta, \mathrm{TNF}-\alpha$ and IL-6, thereby aggravating brain damage (Kraft, Harry, 2011). Therefore, we investigated the effects of prenatal HHC on the levels of inflammatory molecules in cortex of rat offspring. We found that the level of IL-1 $\beta$ in cortex after prenatal HHC was increased on P20 compared to control, whereas no significant differences between the two groups were found either for TNF- $\alpha$ or IL-6.

Our results demonstrate that gestational exposure HHC induces neuroblast migration impairment, cortical cell death, neuroinflammation and neuroglial activation, associated with altered cortex development and impaired neurobehavioral functions in rat offspring.

Acknowledgments. This work was supported by Russian Foundation for Basic Research (18-01500099) and State Budget assignment (AAAA-A19119021290116-1, AAAA-A18-118012290373-7).

\section{References}

1. Vasilev DS, Dubrovskaya NM, Tumanova NL, Zhuravin IA. Prenatal Hypoxia in Different Periods of Embryogenesis Differentially Affects Cell Migration, Neuronal Plasticity, and Rat Behavior in Postnatal Ontogenesis. Front Neurosci. 2016;31(10):126.

2. Shcherbitskaya AD, Milyutina YuP, Zaloznyaya IV, et al. The Effects of Prenatal Hyperhomocysteinemia on the Formation of Memory and the Contents of Biogenic Amines in the Rat Hippocampus. Neurochemical Journal. 2017;11(4):296-301.

3. Rakic P. Specification of cerebral cortical areas. Science. 1988;241:170-176.

4. Kraft AD, Harry GJ. Features of microglia and neuroinflammation relevant to environmental exposure and neurotoxicity. Int J Environ Res Public Health. 2011;8:2980-3018. 